\title{
Trends in the Prevalence and Incidence of Anxiety and Depression in Adult Population in Iran: Findings from Kerman Coronary Artery Diseases Risk factors Study (KERCADRS)
}

\author{
Hamid Najafipour \\ Kerman University of Medical Sciences \\ mohadeseh Shojaei Shahrokhabadi \\ Jiroft University of Medical Sciences \\ Ghodsyeh Banivaheb ( $\sim$ m_shojai82@yahoo.com ) \\ kerman university of medical science \\ Abdolreza Sabahi \\ Kerman University of Medical Sciences \\ Mitra Shadkam \\ Kerman University of Medical Sciences \\ Ali Mirzazadeh \\ University of California San Francisco
}

Primary research

Keywords: anxiety, depression, epidemiology, risk factors, prevalence, incidence, coronary artery disease

Posted Date: August 27th, 2020

DOI: https://doi.org/10.21203/rs.3.rs-64924/v1

License: (c) (1) This work is licensed under a Creative Commons Attribution 4.0 International License.

Read Full License 


\section{Abstract}

Background: Anxiety and depression (A\&D) are common mental disorders with high economical and health burdens. This study aimed to investigate the prevalence and the incidence rate of A\&D and their relationship with socio-demographic and other risk factors and co-morbidities in adults living in southeastern Iran.

Method: We recruited adults (15 to 80 years) in two rounds (2009-2012, 2014-2018) of a populationbased cohort study called Kerman coronary artery disease risk factors study (KERCADRS) in Kerman, Iran. The age-standardized A\&D prevalence was measured among all participants $(n=9996)$ and the fiveyear A\&D incidence rate was measured in those who were free of A\&D in the first round $(n=2813)$. The relationship between A\&D and demographic characteristics, smoking, opium use, obesity and physical activity was assessed by logistic regression models.

Results: Overall, the prevalence of anxiety ( $48.1 \%$ to $16.4 \%$, P-value $<0.001)$ and depression $(5.9 \%$ to $1.3 \%$ P-value $<0.001$ ) decreased between the two rounds. The highest prevalence of anxiety was among people who were unemployed (\%?), smokers (\%?), and opium users (\%?). Young adults, women, those divorced or widowed, and those with obesity and low physical activity had a higher chance for anxiety. The fiveyear incidence rate (person/1000 person-years) was 15.0 for anxiety and 3.9 for depression.

Conclusion: Despite the overall decrease in the prevalence of A\&D, certain groups such as young adults, women, unemployed and those who smoke cigarettes or opium, people with low physical activity and obesity are in need of more targeted interventions.

\section{Background}

Anxiety and depressive disorders are common and very costly complications, which can dramatically affect the quality of life and productivity in any society [1]. According to the Global Burden of Disease 2013 study, major depression ranks second and anxiety disorders rank ninth among all noncommunicable diseases [2]. These disorders have been associated with medical problems such as substance abuse, type 2 diabetes mellitus, and coronary artery disease (CAD) mortality and morbidity [35].

Unlike some cardiovascular risk factors which have mostly genetic basis and are not easily modifiable (eg, hypertension, hyperlipidemia), Anxiety and depressive disorders could be decreased and removed by a proper planning, change of attitude and behavior. Based on a recent systematic review in Iran (2016), the prevalence of anxiety was reported to be $42 \%$ and the prevalence of depression was $44 \%$ [6]. The prevalence of depression has been reported to vary from $6-73 \%$ in different populations [7].

Some epidemiologic studies have shown that in recent years the trend of mental disorders have been increasing in the US and Australia and some have shown stability in their trend in US, Australia and UK [2] An onidominlnainal cturdv in lanan chnimed a varied pattern in the prevalence of depression and Loading [MathJax]/jax/output/CommonHTML/jax.js 
psychological disorders across the country [1]. Due to the differences in demographic characteristics or in mental health outcomes, inconsistency may be observed in trends in the same country and in similar regions.

In Iran, little is known regarding the temporal patterns of psychological disorders in different regions. With a population of 3,164,718 (in 2016), Kerman province constitutes $3.97 \%$ of Iran's population [8]. According to the data from phase 1 of KERCADRS study (2009-2012), the prevalence of anxiety and depression was found to be $48.1 \%$ ( $38.1 \%$ men, $58.6 \%$ women) and $5.9 \%$ ( $4.2 \%$ men, $7.6 \%$ women), respectively [9]. The present study is the second phase of the KERCADRS performed on a larger sample size of 9996 participants to determine the prevalence and predictors of anxiety and depression in the adult population aged 15-80 years from 2014 to 2018 . Therefore, the objective of this study is to comprehensively describe the prevalence and pattern of the anxiety and depression by age, sex, education, and occupation subgroups along with its 5-year incidence rate and also to estimate the association of six other CAD risk factors with the anxiety and depression in a representative urban population in the southeast of Iran. This will provide a better insight into the severity and progress of these two important psychological disorders, which are also known as coronary artery disease risk factors, in this region in the past 5 years.

\section{Methods}

This study is the second phase of the study known as Kerman coronary artery disease risk factors study (KERCADRS), a population-based cohort that focused on risk factors of CAD conducted from 2014 to 2018 on 9996 adult subjects aged 15 to 80 years in the city of Kerman, the largest city in southeastern Iran with a population of close to 750000 . This study was conducted according to the Declaration of Helsinki, and the ethics committee of the Kerman University of Medical Sciences, Iran has approved the study protocol (Ethic code IR.KMU.REC.93/310). Written informed consent was obtained from all participants or their guardian, before taking part in the study, for examination and interview. The study samples were recruited using a non-proportional-to-size one-stage cluster sampling household survey. In brief, we randomly selected 420 zip codes from the post office, each representing a house (called a seed). The recruited individuals were invited to the study setting at the arranged date. The recruitment was continued starting from the house to the surrounding neighborhood until the number of eligible persons in each cluster reached 24, bringing the total target sample size to 10,000. More details about the research methodology and definition of variables in the second phase (which were similar to that of the first phase) are provided in a published paper [10].

\section{Interview and measurements}

A fasting (12-hour) blood sample was taken from each participant at the time of attendance and the serum was separated. The study participants were examined and interviewed by a physician for medical history of CAD risk factors (including anxiety and depression) using a standard structured questionnaire. 
currently smoking at least one cigarette per day), opium use status (1- non-user, 2- occasional user and constant or dependent user), and level of physical activity using the Global Physical Activity Questionnaire (GPAQ). To evaluate the intensity of physical activity, metabolic equivalent (MET) was used. MET is the use of energy in an adult while they are sitting. Moderate physical activity is considered as consuming energy at least four times, and high physical activity at least eight times the energy used while sitting. Body mass index (BMI) was categorized as normal $\left(18.5-24.9 \mathrm{~kg} / \mathrm{m}^{2}\right)$, overweight (25$\left.29.9 \mathrm{~kg} / \mathrm{m}^{2}\right)$, or obese $\left(\geq 30 \mathrm{~kg} / \mathrm{m}^{2}\right)$, and hypertensive individuals as those previously diagnosed with hypertension by a physician, taking anti-hypertension drugs, or having systolic/diastolic blood pressure $\geq 140 / 90 \mathrm{mmHg}$. Blood pressure was taken by the physician twice 30 minutes apart and averaged.

\section{Definition of anxiety and depression}

The level of anxiety and depression were measured using valid translations of Beck Anxiety Inventory (BAI) and Beck Depression Inventory (BDI), respectively. Both anxiety and depression questionnaires were completed during face to face interviews. The total score of each questionnaire ranged from 0 to 63 (containing 21 statements, each scored by a value ranging from 0 to 3 ). In Iran, the validity and reliability of BAI to assess anxiety are $83 \%$ and $80 \%$, respectively. These measures are $85 \%$ and $80 \%$ for BDI for assessment of depression, respectively. The score range for the different levels of depression were 0-15 without symptom, 16-30 mild, 31-46 moderate, and 47-63 severe depression. The score range for the different levels of anxiety was score $0-7$ normal, 8-15 mild, 16-25 moderate, and 26-63 severe anxiety. For anxiety, a score higher than 15 and for depression, a score higher than 30 were taken to be abnormal $[11,12]$.

\section{Incidence rate of anxiety and depression}

Out of the 9996 participants, 2813 individuals free of A\&D had also participated in the previous phase of the study. We used the same method to calculate the incidence rate for anxiety and depression. Therefore, for the purpose of brevity, we only present the method for calculating incidence rate of depression here. To calculate the incidence rate of depression, we used the data obtained from participants who had been judged normal in phase 1, and therefore, were at the risk of developing depression during the 5-year interval between the two phases (Fig. 1). Therefore, 348 cases out of the 5895 participants who participated in phase 1 (5.9\%) and had shown different levels of depression were excluded from the incidence rate calculation. Out of the remaining participants (5547 cases), 2734 persons ( $46.4 \%$ of participants) were lost to follow-up/died. The number of new depression cases (among the total of 5547 cases) identified during the period of follow up was considered as numerator. For those who were normal in the phase 1 visit, the time difference (in year) between the visit in phase 1 and the visit in phase 2 was calculated as person-years at risk. Therefore the denominator was the sum of the time the 5547 persons who were at risk of developing depression were followed (person-year). We assumed those who were lost to follow-up had followed on average 2.5 years (half of overall follow time between phase 1 and 2) before being lost to follow-up. Then incidence rate (expressed as person per 1000 person-years) was calculated by the formula [13]: 


$$
\text { Incidencerate }=\frac{\text { Numberofnewcasesofdepressionduring5years }}{\text { Totalperson }- \text { yearsforallpersonsatrisk }} \times 1000
$$

Figure 1 here

\section{Statistical analysis}

Numeric variables were described by Mean (SD) and categorical/ordinal variables by $n$ (\%). Data management and all statistical analyses were conducted using STATA version 14 (Stata Corp, LP. 2015). Data were analyzed using the survey data analysis package. Because of the non-proportionate to size sampling method, the total estimates were standardized based on the real sex-age distribution of the target population (national census of Kerman population size for 2016). We reported weighted prevalence for anxiety and depression. Multivariate survey logistic regression models were used to determine the potential predictors of anxiety and depression, and then, adjusted odds ratios (OR) were obtained. The CAD risk factors sex, age, marital status, education level, occupation, cigarette smoke, opium use, physical activity, BMI, and hypertension were included in the model.

\section{Results}

We analyzed the data for 9,996 persons, $40.6 \%$ of whom were male. Their mean age was $46.2 \pm$ 15.7 years. The abnormal (moderate to severe) levels of anxiety and depression were $41.6 \%$ and $16.0 \%$, respectively (Fig. 2). The prevalence of anxiety (48.1-16.4\%) and depression (5.9-1.3\%) significantly decreased between the two rounds $(p<0.001)$. The decrease in the prevalence of anxiety and depression between the two study rounds were also significant in subgroups of gender and age $(P<0.001$, Fig. 2$)$.

Figure 2 here

Compared to their counterparts, adjusted analysis showed that people who were female (AOR 2.26), married (AOR 1.06), divorced (AOR 1.19) or widowed (AOR 1.30), hypertension (AOR 1.25), and overweight/obesity (AOR 1.07) were positively, and employment (AOR $0.79-0.55$ ), higher education level $(0.77-0.50)$ and advanced age (AOR $0.68-0.37)$ were negatively associated with anxiety (Table 1$)$. 
Table 1

Standardized prevalence, $\%(95 \% \mathrm{Cl})$ of anxiety and depression, and adjusted odds ratio $(95 \% \mathrm{Cl})$ for predictors of anxiety and depression, Community-Based Cohort Study (KERCADR 2nd Phase - $\mathrm{n}=9996$ ), Kerman, Iran, 2014-2018.

\begin{tabular}{|c|c|c|c|c|c|c|}
\hline \multirow[t]{2}{*}{ Subgroups } & \multicolumn{3}{|l|}{ Anxiety } & \multicolumn{3}{|l|}{ Depression } \\
\hline & $\begin{array}{l}\text { Abnormal } \\
\%(95 \% \mathrm{Cl})\end{array}$ & Adjusted OR & $\begin{array}{l}\mathrm{P}- \\
\text { value }\end{array}$ & $\begin{array}{l}\text { Abnormal } \\
\%(95 \% \mathrm{Cl})\end{array}$ & Adjusted OR & $\begin{array}{l}\mathrm{P} \text { - } \\
\text { value }\end{array}$ \\
\hline \multicolumn{7}{|l|}{ Sex } \\
\hline Male & $\begin{array}{l}9.2(8.1- \\
10.3)\end{array}$ & 1 & & $\begin{array}{l}0.5(0.3- \\
0.7)\end{array}$ & 1 & \\
\hline Female & $\begin{array}{l}21.5(20.3- \\
22.7)\end{array}$ & $\begin{array}{l}2.26(2.17- \\
2.36)\end{array}$ & $<001$ & $\begin{array}{l}2.0(1.6- \\
2.4)\end{array}$ & $\begin{array}{l}2.56(2.40- \\
2.73)\end{array}$ & $\begin{array}{l}<.001 \\
0.001\end{array}$ \\
\hline \multicolumn{7}{|l|}{$\begin{array}{l}\text { Age } \\
\text { group(years) }\end{array}$} \\
\hline $15-24$ & $\begin{array}{l}14.6(12.4- \\
17.1)\end{array}$ & 1 & & $\begin{array}{l}0.9(0.5- \\
1.8)\end{array}$ & 1 & \\
\hline $25-34$ & $\begin{array}{l}16.0(14.4- \\
17.8)\end{array}$ & $\begin{array}{l}0.68(0.64- \\
0.73)\end{array}$ & $<0.001$ & $\begin{array}{l}1.6(1.1- \\
2.3)\end{array}$ & $\begin{array}{l}0.93(0.84- \\
1.02)\end{array}$ & 0.110 \\
\hline $35-44$ & $\begin{array}{l}18.8(17.2- \\
20.6)\end{array}$ & $\begin{array}{l}0.65(0.61- \\
0.70)\end{array}$ & $<0.001$ & $\begin{array}{l}1.5(1.1- \\
2.1)\end{array}$ & $\begin{array}{l}0.91(0.83- \\
1.01)\end{array}$ & 0.064 \\
\hline $45-54$ & $\begin{array}{l}16.7(15.1- \\
18.3)\end{array}$ & $\begin{array}{l}0.50(0.46- \\
0.54)\end{array}$ & $<001$ & $\begin{array}{l}1.5(1.1- \\
2.2)\end{array}$ & $\begin{array}{l}0.80(0.72- \\
0.89)\end{array}$ & $\begin{array}{l}<.001 \\
0.001\end{array}$ \\
\hline $55-64$ & $\begin{array}{l}17.2(15.6- \\
18.9)\end{array}$ & $\begin{array}{l}0.47(0.43- \\
0.51)\end{array}$ & $<0.001$ & $\begin{array}{l}1.4(1.0- \\
2.0)\end{array}$ & $\begin{array}{l}0.77(0.69- \\
0.87)\end{array}$ & $\begin{array}{l}< \\
0.001\end{array}$ \\
\hline+65 & $\begin{array}{l}12.8(11.1- \\
14.7)\end{array}$ & $\begin{array}{l}0.37(0.34- \\
0.42)\end{array}$ & $<001$ & $\begin{array}{l}0.6(0.3- \\
1.2)\end{array}$ & $\begin{array}{l}0.59(0.51- \\
0.68)\end{array}$ & $\begin{array}{l}<.001 \\
0.001\end{array}$ \\
\hline \multicolumn{7}{|c|}{ Marital Status } \\
\hline Single & $\begin{array}{l}12.3(10.5- \\
14.3)\end{array}$ & 1 & & $\begin{array}{l}1.1(0.7- \\
1.9)\end{array}$ & 1 & \\
\hline Married & $\begin{array}{l}17.5(16.5- \\
18.4)\end{array}$ & $\begin{array}{l}1.06(1.01- \\
1.12)\end{array}$ & 0.033 & $\begin{array}{l}1.3(1.0- \\
1.6)\end{array}$ & $\begin{array}{l}1.16(1.10- \\
1.22)\end{array}$ & $\begin{array}{l}< \\
0.001\end{array}$ \\
\hline Divorced & $\begin{array}{l}21.8(17.9- \\
26.2)\end{array}$ & $\begin{array}{l}1.19(1.04- \\
1.37)\end{array}$ & 0.014 & $\begin{array}{l}6.2(2.5- \\
14.4)\end{array}$ & $\begin{array}{l}2.70(2.35- \\
3.13)\end{array}$ & $\begin{array}{l}<.001 \\
0.001\end{array}$ \\
\hline Widowed & $\begin{array}{l}31.4(22.1- \\
42.3)\end{array}$ & $\begin{array}{l}1.30(1.16- \\
1.43)\end{array}$ & $<.001$ & $\begin{array}{l}3.1(1.5- \\
6.0)\end{array}$ & $\begin{array}{l}2.45(2.02- \\
2.49)\end{array}$ & <. 001 \\
\hline $\begin{array}{l}\text { Education } \\
\text { Level }\end{array}$ & & & & & & \\
\hline
\end{tabular}




\begin{tabular}{|c|c|c|c|c|c|c|}
\hline \multirow[t]{2}{*}{ Subgroups } & \multicolumn{3}{|l|}{ Anxiety } & \multicolumn{3}{|l|}{ Depression } \\
\hline & $\begin{array}{l}\text { Abnormal } \\
\%(95 \% \mathrm{Cl})\end{array}$ & Adjusted OR & $\begin{array}{l}\mathrm{P}- \\
\text { value }\end{array}$ & $\begin{array}{l}\text { Abnormal } \\
\%(95 \% \mathrm{Cl})\end{array}$ & Adjusted OR & $\begin{array}{l}\mathrm{P} \text { - } \\
\text { value }\end{array}$ \\
\hline Illiterate & $\begin{array}{l}22.9(19.9- \\
26.3)\end{array}$ & 1 & & $\begin{array}{l}1.9(1.1- \\
2.5)\end{array}$ & 1 & \\
\hline Primary & $\begin{array}{l}21.2(19.1- \\
23.5)\end{array}$ & $\begin{array}{l}0.77(0.71- \\
0.83)\end{array}$ & $<.001$ & $\begin{array}{l}1.6(1.2- \\
2.0)\end{array}$ & $\begin{array}{l}0.90(0.82- \\
0.99)\end{array}$ & $<.001$ \\
\hline Secondary & $\begin{array}{l}17.1(16.0- \\
18.3)\end{array}$ & $\begin{array}{l}0.68(0.64- \\
0.74)\end{array}$ & $\begin{array}{l}< \\
0.001\end{array}$ & $\begin{array}{l}1.3(0.8- \\
2.7)\end{array}$ & $\begin{array}{l}0.79(0.71- \\
0.86)\end{array}$ & $<.001$ \\
\hline University & $\begin{array}{l}11.2(9.7- \\
13.0)\end{array}$ & $\begin{array}{l}0.50(0.46- \\
0.54)\end{array}$ & $<.001$ & $\begin{array}{l}0.5(0.3- \\
1.0)\end{array}$ & $\begin{array}{l}0.51(0.46- \\
0.56)\end{array}$ & $\begin{array}{l}<.001 \\
0.00\end{array}$ \\
\hline \multicolumn{7}{|l|}{ Occupation } \\
\hline Unemployed & $\begin{array}{l}21.3(20.0- \\
22.5)\end{array}$ & 1 & & $\begin{array}{l}1.7(1.1- \\
2.5)\end{array}$ & 1 & \\
\hline Student/Soldier & $\begin{array}{l}12.0(9.7- \\
14.9)\end{array}$ & $\begin{array}{l}0.55(0.50- \\
0.60)\end{array}$ & $\begin{array}{l}< \\
0.001\end{array}$ & $\begin{array}{l}0.5(.3- \\
1.0)\end{array}$ & $\begin{array}{l}0.34(0.30- \\
0.38)\end{array}$ & $\begin{array}{l}< \\
0.001\end{array}$ \\
\hline Self-employed & $\begin{array}{l}12.3(10.9- \\
13.9)\end{array}$ & $\begin{array}{l}0.95(0.91- \\
0.99)\end{array}$ & 0.046 & $\begin{array}{l}1.6(1.2- \\
2.0)\end{array}$ & $\begin{array}{l}0.97(0.91- \\
1.04)\end{array}$ & 0.376 \\
\hline Office clerk & $\begin{array}{l}10.0(8.1- \\
12.3)\end{array}$ & $\begin{array}{l}0.79(0.75- \\
0.84)\end{array}$ & $<0.001$ & $\begin{array}{l}1.5(0.8- \\
2.7)\end{array}$ & $\begin{array}{l}0.54(0.49- \\
0.59)\end{array}$ & $\begin{array}{l}<.001 \\
0.001\end{array}$ \\
\hline \multicolumn{7}{|l|}{$\begin{array}{l}\text { Cigarette } \\
\text { Smoke }\end{array}$} \\
\hline No & $\begin{array}{l}16.6(15.7- \\
17.5)\end{array}$ & 1 & & $\begin{array}{l}1.4(1.1- \\
1.7)\end{array}$ & 1 & \\
\hline Yes & $\begin{array}{l}14.7(12.1- \\
17.8)\end{array}$ & $\begin{array}{l}1.39(1.31- \\
1.47)\end{array}$ & $\begin{array}{l}< \\
0.001\end{array}$ & $\begin{array}{l}1.1(0.6- \\
2.2)\end{array}$ & $\begin{array}{l}1.86(1.72- \\
2.01)\end{array}$ & $\begin{array}{l}< \\
0.001\end{array}$ \\
\hline \multicolumn{7}{|l|}{ Opium Use } \\
\hline No & $\begin{array}{l}16.4(15.5- \\
17.3)\end{array}$ & 1 & & $\begin{array}{l}1.3(1.0- \\
1.5)\end{array}$ & 1 & \\
\hline Yes & $\begin{array}{l}17.4(15.0- \\
20.1)\end{array}$ & $\begin{array}{l}1.22(1.16- \\
1.29)\end{array}$ & $\begin{array}{l}<.001 \\
0.01\end{array}$ & $\begin{array}{l}2.4(1.5- \\
3.9)\end{array}$ & $\begin{array}{l}1.72(1.61- \\
1.83)\end{array}$ & $\begin{array}{l}< \\
0.001\end{array}$ \\
\hline \multicolumn{7}{|l|}{$\begin{array}{l}\text { Physical } \\
\text { Activity }\end{array}$} \\
\hline Low & $\begin{array}{l}18.3(16.9- \\
19.8)\end{array}$ & 1 & & $\begin{array}{l}1.4(0.9- \\
1.7)\end{array}$ & 1 & \\
\hline Moderate & $\begin{array}{l}15.9 \\
1711\end{array}$ & $\begin{array}{l}0.91 \text { (0.83- } \\
\text { nan) }\end{array}$ & $\begin{array}{l}< \\
0.001\end{array}$ & $\begin{array}{l}1.6(1.2- \\
2.2)\end{array}$ & $\begin{array}{l}0.96(0.91- \\
1.02)\end{array}$ & 0.230 \\
\hline
\end{tabular}




\begin{tabular}{|c|c|c|c|c|c|c|}
\hline \multirow[t]{2}{*}{ Subgroups } & \multicolumn{3}{|l|}{ Anxiety } & \multicolumn{3}{|l|}{ Depression } \\
\hline & $\begin{array}{l}\text { Abnormal } \\
\%(95 \% \mathrm{Cl})\end{array}$ & Adjusted OR & $\begin{array}{l}\mathrm{P}- \\
\text { value }\end{array}$ & $\begin{array}{l}\text { Abnormal } \\
\%(95 \% \mathrm{Cl})\end{array}$ & Adjusted OR & $\begin{array}{l}\mathrm{P} \text { - } \\
\text { value }\end{array}$ \\
\hline High & $\begin{array}{l}13.8(11.9- \\
16.0)\end{array}$ & $\begin{array}{l}0.88(0.84- \\
0.92)\end{array}$ & $<0.001$ & $\begin{array}{l}0.9(0.5- \\
1.6)\end{array}$ & $\begin{array}{l}0.91(0.87- \\
0.95)\end{array}$ & $\begin{array}{l}< \\
0.001\end{array}$ \\
\hline \multicolumn{7}{|l|}{ BMI } \\
\hline Normal & $\begin{array}{l}14.5(13.2- \\
16.0)\end{array}$ & 1 & & $\begin{array}{l}1.4(1.0- \\
2.0)\end{array}$ & 1 & \\
\hline Overweight & $\begin{array}{l}16.5(15.2- \\
18.0)\end{array}$ & $\begin{array}{l}1.07(1.03- \\
1.10)\end{array}$ & $\begin{array}{l}< \\
0.001\end{array}$ & $\begin{array}{l}1.1(0.8- \\
1.6)\end{array}$ & $\begin{array}{l}0.91(0.87- \\
0.95)\end{array}$ & $\begin{array}{l}<.001 \\
0.00\end{array}$ \\
\hline Obese & $\begin{array}{l}19.7(18.0- \\
21.5)\end{array}$ & $\begin{array}{l}1.07(1.02- \\
1.11)\end{array}$ & 0.001 & $\begin{array}{l}1.6(1.1- \\
2.1)\end{array}$ & $\begin{array}{l}1.13(1.1- \\
1.19)\end{array}$ & $\begin{array}{l}<.001 \\
0.001\end{array}$ \\
\hline \multicolumn{7}{|l|}{ Hypertension } \\
\hline Normal & $\begin{array}{l}15.4(12.7- \\
18.5)\end{array}$ & 1 & & $\begin{array}{l}1.1(0.9- \\
1.7)^{(0.9}\end{array}$ & 1 & \\
\hline Hypertensive & $\begin{array}{l}16.5(15.7- \\
17.4)\end{array}$ & $\begin{array}{l}1.25(1.20- \\
1.31)\end{array}$ & $<0.001$ & $\begin{array}{l}0.9(0.6- \\
1.6)\end{array}$ & $\begin{array}{l}1.00(0.94- \\
1.07)\end{array}$ & 0.938 \\
\hline
\end{tabular}

Except for hypertension who had no association with depression, all other variables showed positive or negative associations with the same trend as they did with anxiety, with the highest AOR for female gender (2.56) and divorced (2.70), and lowest AOR with student/soldier (0.34) and university education level (0.51) (Table 1).

Table 1 here

\section{Predictors of anxiety and depression}

Multiple logistic regression analysis showed that the chances of developing anxiety and depression were 2.26 (95\% Cl: $2.17-2.36)$ and 2.56 (95\% Cl: 2.40-2.73) times higher in females than it was in males, respectively. Considering the 15-24 age group as reference, the chance of anxiety and depression for participants showed a reducing trend with increase in age (Table 1). Our result suggested that the adjusted OR for both disorders decreased by about $50 \%$ among the most highly educated people. Considering unemployment as reference, being a government clerk was associated with $21 \%$ (OR $=0.79$, $95 \% \mathrm{Cl}: 0.75-0.84)$ and $46 \%(\mathrm{OR}=0.54,95 \% \mathrm{Cl}: 0.49-0.59)$ lower odds of developing anxiety and depression, respectively. The adjusted OR for anxiety and depression significantly increased among cigarette smokers and opium users. In terms of physical activity and obesity, the odds significantly increased in the obese and people with low physical activity.

\section{Innidanno rata of anvioty and depression}


Overall, the incidence rate per 1000-person years was 15.0 for anxiety and 3.9 for depression. A higher incidence rate of anxiety and depression was observed in women compared to men (Table 2). Also, a higher incidence rate of anxiety and depression was observed in people with lower education (compared to those with higher education) and obesity. Cigarette smoking reduced the incidence rate of anxiety and depression. However, opium use and low physical activity were associated with a higher incidence rate of depression. 
Table 2

Overall and subgroup 5-year incidence rate (person per 1,000 person-years) of anxiety and depression among adult population in Kerman, Iran (Community-Based Cohort Study (KERCADR 1st phase 20092012 and 2nd Phase 2014-2018, $n=2813$ match cases).

\begin{tabular}{|c|c|c|c|c|c|c|}
\hline \multirow[t]{2}{*}{ Subgroups } & \multicolumn{3}{|c|}{ Anxiety } & \multicolumn{3}{|c|}{ Depression } \\
\hline & $\begin{array}{l}\text { new } \\
\text { cases }\end{array}$ & $\begin{array}{l}\text { Person- } \\
\text { years }\end{array}$ & Incidence Rate & $\begin{array}{l}\text { new } \\
\text { cases }\end{array}$ & $\begin{array}{l}\text { Person- } \\
\text { years }\end{array}$ & $\begin{array}{l}\text { Incidence } \\
\text { Rate }\end{array}$ \\
\hline Overall & 97 & 6466.5 & $\begin{array}{l}15.0(12.2- \\
18.3)\end{array}$ & 27 & 6923.5 & $\begin{array}{l}3.9(2.6- \\
5.7)\end{array}$ \\
\hline \multicolumn{7}{|l|}{ Sex } \\
\hline Male & 53 & 4250.5 & $\begin{array}{l}12.5(9.3- \\
16.3)\end{array}$ & 10 & 3571 & $\begin{array}{l}2.8(1.3- \\
5.2)\end{array}$ \\
\hline Female & 44 & 2210.5 & $\begin{array}{l}19.9(14.5- \\
26.7)\end{array}$ & 17 & 3269.5 & $5.2(3.0-8.3)$ \\
\hline \multicolumn{7}{|l|}{$\begin{array}{l}\text { Education } \\
\text { Level }\end{array}$} \\
\hline Illiterate & 9 & 482.5 & $\begin{array}{l}18.7(8.5- \\
35.4)\end{array}$ & 2 & 526 & $\begin{array}{l}3.8(0.5- \\
13.7)\end{array}$ \\
\hline Primary & 16 & 897.5 & $\begin{array}{l}17.8(10.2- \\
29.0)\end{array}$ & 7 & 1093.5 & $\begin{array}{l}6.4(2.6- \\
13.2)\end{array}$ \\
\hline Secondary & 48 & 3252.5 & $\begin{array}{l}14.8(10.9- \\
19.6)\end{array}$ & 13 & 3513.5 & $3.7(2.0-6.3)$ \\
\hline University & 24 & 1832.5 & $\begin{array}{l}13.1(8.4- \\
19.5)\end{array}$ & 5 & 1666.5 & $\begin{array}{l}3.0(1.0- \\
7.0)\end{array}$ \\
\hline \multicolumn{7}{|l|}{$\begin{array}{l}\text { Cigarette } \\
\text { Smoke }\end{array}$} \\
\hline No & 89 & 5629 & $\begin{array}{l}15.8(12.7- \\
19.5)\end{array}$ & 25 & 6097.5 & $\begin{array}{l}4.1(2.7- \\
6.1)\end{array}$ \\
\hline Yes & 8 & 575 & $13.9(6.0-27.4)$ & 2 & 859 & $\begin{array}{l}2.3(0.3- \\
8.4)\end{array}$ \\
\hline \multicolumn{7}{|l|}{ Opium Use } \\
\hline No & 84 & 5250.5 & $\begin{array}{l}16.0(12.8- \\
19.8)\end{array}$ & 23 & 6052.5 & $\begin{array}{l}3.8(2.4- \\
5.7)\end{array}$ \\
\hline Yes & 13 & 928.5 & $\begin{array}{l}14.0(7.4- \\
23.9)\end{array}$ & 4 & 793.5 & $\begin{array}{l}5.0(1.4- \\
12.9)\end{array}$ \\
\hline \multicolumn{7}{|l|}{$\begin{array}{l}\text { Physical } \\
\text { Activity }\end{array}$} \\
\hline Low & 47 & 2737.5 & $\begin{array}{l}17.2(12.6- \\
22.8)\end{array}$ & 14 & 2916.5 & $\begin{array}{l}4.8(2.6- \\
8.1)\end{array}$ \\
\hline
\end{tabular}




\begin{tabular}{|c|c|c|c|c|c|c|}
\hline \multirow[t]{2}{*}{ Subgroups } & \multicolumn{3}{|c|}{ Anxiety } & \multicolumn{3}{|c|}{ Depression } \\
\hline & $\begin{array}{l}\text { new } \\
\text { cases }\end{array}$ & $\begin{array}{l}\text { Person- } \\
\text { years }\end{array}$ & Incidence Rate & $\begin{array}{l}\text { new } \\
\text { cases }\end{array}$ & $\begin{array}{l}\text { Person- } \\
\text { years }\end{array}$ & $\begin{array}{l}\text { Incidence } \\
\text { Rate }\end{array}$ \\
\hline Moderate & 31 & 2912.5 & $\begin{array}{l}10.6(7.2- \\
15.1)\end{array}$ & 10 & 3289.5 & $\begin{array}{l}3.0(1.5- \\
5.6)\end{array}$ \\
\hline High & 19 & 840 & $\begin{array}{l}22.6(13.6- \\
35.3)\end{array}$ & 3 & 739.5 & $\begin{array}{l}4.1(0.8- \\
11.9)\end{array}$ \\
\hline \multicolumn{7}{|l|}{ BMI } \\
\hline Normal & 34 & 3591.5 & $9.5(6.6-13.2)$ & 8 & 3076 & $\begin{array}{l}2.6(1.1- \\
5.1)\end{array}$ \\
\hline Overweight & 27 & 1925 & $\begin{array}{l}14.0(9.2- \\
20.4)\end{array}$ & 10 & 2325.5 & $\begin{array}{l}4.3(2.1- \\
7.9)\end{array}$ \\
\hline Obese & 36 & 917.5 & $\begin{array}{l}39.2(27.5- \\
54.3)\end{array}$ & 9 & 1451.5 & $\begin{array}{l}6.2(2.8- \\
11.8)\end{array}$ \\
\hline
\end{tabular}

Table 2 here

\section{Discussion}

Our findings suggested that the overall prevalence of both anxiety and depression decreased in past five years. However, such mental disorders are more frequent among certain groups of people such as young adults, women, unemployed and those who smoke cigarettes or opium, people with low physical activity and obesity; who were in need of more targeted interventions. We also found that the five-year incidence rate of anxiety is much higher than five-year incidence rate depression (15.0 vs. 3.9).

Overall, the findings of this study showed that currently $41.6 \%$ of the population had mild to severe levels of anxiety and $16.0 \%$ had mild to severe levels of depression, but both were significantly lower than corresponding values in phase 1 of the study $(77.1 \%$ and $34.7 \%$, respectively) [9]. The reason for this is not clear for us but substantial increase in the provision of treatment facilities (including mental health services) by the government in the past five years may have played a role [14]. In Iran, in recent years, the government has implemented a health promotion plan to cover treatment costs by offering more efficient health insurance to almost all Iranians. Social determinants such as poverty and unemployment are important factors for mental health [15] as it was shown that the prevalence of these disorders was highest in unemployed and lowest in office clerks (Table 1). The other probable influencing factor may be the agreement of the Joint Comprehensive Plan of Action in connection to Iran's nuclear deal between Iran and the $5+1$ countries, which raised the hope of lifting the economic sanctions against Iran and freeing billions of dollars in oil revenue and frozen assets. This plan was signed in April 2015 a few months after the commencement of the current study. The third possible explanation is that people have become more aware of common mental disorders. This may have been caused by the increase in the 
in phase 1 had university education. This figure increased to 19.8 percent in phase 2 . A reverse association was found between the level of education and the prevalence of anxiety and depression in the present study (Table 1).

The second finding of the study was that the prevalence and incidence rate of anxiety and depression were higher in women than in men. Although these results differ from some studies (some of which show no difference) $[1,2,16]$, they are consistent with the findings of some others $[17,18]$. After adjusting the impact of other covariates, there was a significant relationship between sex and anxiety and depression. The incidence of anxiety and depression in women was approximately twice that of men. The present findings seem to be consistent with other research which has found that sex is a contributing factor in anxiety and depression $[19,20]$. This is also confirmed by our earlier observations [9]. This result may be explained by the fact that women experience more positive and negative emotions and with greater intensity than men do [21].

The 5-year incidence rate of anxiety and depression symptoms were 15.0 and 3.9 persons/1000 personyears, respectively. The recorded incidence of anxiety and depression in women was slightly higher than it was in men. It is difficult to compare our findings with other incidence studies because of difference in socio-economic conditions, time span, and follow-up durations. Our findings seem to be consistent with other researches, which identified a greater incidence of anxiety and depression among women [16, 22]. The reduction of prevalence of anxiety and depression overall and in both genders during the last five years may be due to the low incidence rate of these disorders in this time period.

Surprisingly, despite the high prevalence of anxiety and depression in old age, one unanticipated finding was that the chance of anxiety and depression in the 15-24 age group was higher than it was in other groups. The possible mechanism may be that Iran is a country with a highly-educated young population. Unfortunately the rate of unemployment among educated people is high in Iran, and it was shown that employment is a very important factor in reducing anxiety and depression (Table 2),

Another risk factor associated with anxiety and depression was discordant marital life (separated/widowed). This finding is consistent with previous studies [20, 23, 24]. Loss of spouse is associated with a variety of adverse health outcomes including decreased physical well-being, increased mortality risk, and poor cognitive and functional health compared to married counterparts. Poor mental health is one of the most immediate responses to loss of spouse $[25,26]$.

Another important finding of this study was that university education is a protective factor against anxiety and depression. The fact that low level of education is an independent risk factor for mental and mood disorders and anxiety, has been shown in different studies [9, 20,27]. Higher education improves self-esteem, vulnerability, and living standards [28]. Moreover, educated people have more hope of finding a suitable job and sufficient income, which contributes greatly to their mental health in our community [9].

In line with previous studies, our results demonstrated that unemployment increases the chance of 
development and progression of psychiatric disorders and strong evidence is available in this regard for depression and anxiety disorders [31-33]. Unemployed people may develop some degree of anxiety and depression due to income inequality and the feeling of uselessness, failure, and incompetence [34], especially in countries with weak social security support and unemployment insurance like Iran. A longitudinal study showed a causal relation between socioeconomic position and depressive symptoms. It indicated that poor socioeconomic conditions lead to depression, which, in turn, can cause further damage to patients' economic prospects [35].

The results illustrate that high physical activity decreased the chance of developing anxiety and depression. This can be due to the fact that exercising increases endorphin release in the brain. Endorphins have been proved to cause the feeling of happiness [36].

The results provided evidence that obesity may lead to anxiety and depression or be one of their consequences. Obese individuals had a significantly higher risk of developing major anxiety and depressive disorder over the 5-year follow-up period. There are a few studies that have tested obesity as a predictor of anxiety and depression, but most of them found that obesity or increased body mass index (BMI) were associated prospectively with anxiety and depression [37, 38]. Stigma and social prejudice against obesity may mediate this link [37,39]. Functional impairment, which is greater among obese individuals [40], may also mediate the effect of weight status on anxiety and depression.

Cigarette smoking and opium use were highly comorbid with anxiety and depression (Table 1). This was consistent with the results of a review study that showed smoking was strongly associated with anxiety disorders and clinical depression [41]. Sonntag et al. found that individuals with social phobia were more likely to also have nicotine dependence [42]. Many individuals may smoke because of the presumed calming effects of nicotine and as a way of managing their anxiety. However smoking may rather serve to exacerbate symptoms by increasing the heart rate, blood pressure, and plasma norepinephrine and epinephrine [43]. Some studies indicate that $70 \%$ of depressed people have a history of drug abuse and $75 \%$ of the people with a history of drug abuse suffer from depression. In fact, drug users face financial problems, unemployment, suicidal tendencies, and low social support, all of which can lead to anxiety and depression [44].

The collected data showed that hypertension was associated with an increased chance of anxiety, but not with an increased chance of depression. It is possible that labeling individuals as hypertensive may also play a role in the inter-relationships of stress, anxiety, and high BP $[45,46]$. This is consistent with several other studies that have demonstrated higher psychological distress and lower well-being in hypertensive patients $[45,46]$. Consistently, in a previous study, depressive disorder was associated with lower blood pressure [47].

\section{Conclusion}

Overall, the results showed some promising signs of reduction in the prevalence of anxiety and Loading [MathJax]/jax/output/CommonHTML/jax.js owever higher prevalence in young people and females, along 
with their association with unemployment, smoking, opium use, low physical activity, and obesity, all prevalent in the region, highlight the importance of screening for depression and anxiety disorders and preventive or educational interventions to change unhealthy lifestyles to reduce future healthcare costs.

\section{Declarations}

Ethical approval and consent to participate: Prior to commencing the study, ethical clearance for the research was sought from the ethics committee of the Kerman University of Medical Sciences, Iran (Ethic code IR.KMU.REC.93/310). Written informed consent was obtained from all participants or their parent or guardian (children under 18 years old), before taking part in the study, for examination and interview

Consent for publication: consent for publication was obtained from authors.

Availability of data and materials: The data used in our study is provided by Cardiovascular Research Center, Institute of Basic and Clinical Physiology Sciences, Kerman University of Medical Sciences. Data sharing is subject to the reader inquiry.

Competing interests: Authors declare that they have no competing interests.

Authors' contribution: $\mathrm{HN}$ and AM designed the study. MSS developed the analytic approach. $\mathrm{HN}$ and MSS wrote the first draft of the paper. GB and AS performed the clinical examination of the participants and helped in interpretation of the results. MSF worked in project administration and helped in data collection. All authors contributed in reviewing and finalizing the paper

Acknowledgements and funding: The KERCADR study phase 2 was funded by the Deputy of Research and Technology at Kerman University of Medical Sciences (Grant No: KMU.REC.1393/310). The authors would like to sincerely thank the participants of the study and especially their colleagues in the Physiology Research Center who helped to recruit, interview, and examine the study participants.

\section{References}

1. Nishi D, Susukida R, Usuda K, Mojtabai R, Yamanouchi Y. Trends in the prevalence of psychological distress and the use of mental health services from 2007 to 2016 in Japan. J Affect Disord. 2018;239:208-13.

2. Jorm AF, Patten SB, Brugha TS, Mojtabai R. Has increased provision of treatment reduced the prevalence of common mental disorders? Review of the evidence from four countries. World Psychiatry. 2017;16(1):90-9.

3. Celano CM, Millstein RA, Bedoya CA, et al. Association between anxiety and mortality in patients with coronary artery disease: A meta-analysis. American heart journal. 2015;170(6):1105-15.

4. Smith KJ, Béland $M$, Clyde $M$, et al. Association of diabetes with anxiety: a systematic review and meta-analysis. J Psychosom Res. 2013;74(2):89-99. 
5. Roupa Z, Koulouri A, Sotiropoulou P, et al. Anxiety and depression in patients with type 2 diabetes mellitus, depending on sex and body mass index. Health science journal. 2009;3(1):32-40.

6. Valizadeh R, Sarokhani D, Sarokhani M, et al. A study of prevalence of anxiety in Iran: Systematic review and meta-analysis. Der Pharma Chemica. 2016.

7. Montazeri A, Mousavi SJ, Omidvari S, et al. Depression in Iran: a systematic review of the literature (2000-2010). Payesh (Health Monitor). 2013;12(6):567-94.

8. Statistical Center of Iran. National Census of Population and Housing of Iran [Available from: http://www.amar.org.ir/Default.aspx?tabid=133.

9. Najafipour H, Banivaheb G, Sabahi A, et al. Prevalence of anxiety and depression symptoms and their relationship with other coronary artery disease risk factors: A population-based study on 5900 residents in Southeast Iran. Asian journal of psychiatry. 2016;20:55-60.

10. Najafipour $\mathrm{H}$, Mirzazadeh A, Haghdoost A, et al. Coronary artery disease risk factors in an urban and peri-urban setting, Kerman, Southeastern Iran (KERCADR study): methodology and preliminary report. Iranian journal of public health. 2012;41(9):86.

11. Khesht-Masjedi MF, Omar Z, Masoleh SMK. Psychometrics properties of the Persian version of Beck Anxiety Inventory in North of Iranian adolescents. International Journal of Educational Psychological Researches. 2015;1(2):145.

12. Hojat M, Shapurian R, Mehryar AH. Psychometric properties of a Persian version of the short form of the Beck Depression Inventory for Iranian college students. Psychological reports. 1986;59(1):331-8.

13. Dicker RC, Coronado F, Koo D, Parrish RG. Principles of epidemiology in public health practice; an introduction to applied epidemiology and biostatistics. 2006.

14. Olyaeemanesh A, Behzadifar M, Mousavinejhad N, et al. Iran's health system transformation plan: a SWOT analysis. Medical journal of the Islamic Republic of Iran. 2018;32:39.

15. Fisher M, Baum F. The social determinants of mental health: implications for research and health promotion. Australian New Zealand Journal of Psychiatry. 2010;44(12):1057-63.

16. Weinberger A, Gbedemah M, Martinez A, et al. Trends in depression prevalence in the USA from 2005 to 2015: widening disparities in vulnerable groups. Psychological medicine. 2018;48(8):1308-15.

17. Baxter AJ, Scott KM, Ferrari AJ, et al. Challenging the myth of an "epidemic" of common mental disorders: trends in the global prevalence of anxiety and depression between 1990 and 2010. Depress Anxiety. 2014;31(6):506-16.

18. Baxter A, Scott K, Vos T, Whiteford H. Global prevalence of anxiety disorders: a systematic review and meta-regression. Psychological medicine. 2013;43(5):897-910.

19. Sajjadi H, Kamal SHM, Rafiey H, et al. A systematic review of the prevalence and risk factors of depression among Iranian adolescents. Global journal of health science. 2013;5(3):16.

20. Rancans E, Renemane L, Kivite-Urtane A, Ziedonis D. Prevalence and associated factors of mental disorders in the nationwide primary care population in Latvia: a cross-sectional study. Annals of general psychiatry. 2020;19(1):1-10.

Loading [MathJax]/jax/output/CommonHTML/jax.js

Page 15/19 
21. Veytia-López M, Calvete E, Sánchez-Álvarez N, Guadarrama-Guadarrama R. Relationship between stressful life events and emotional intelligence in Mexican adolescents: Male vs. female comparative study. Salud Mental. 2019;42(6):261-8.

22. Ferrari A, Somerville A, Baxter A, et al. Global variation in the prevalence and incidence of major depressive disorder: a systematic review of the epidemiological literature. Psychological medicine. 2013;43(3):471-81.

23. ZamZam R, Thambu M, Midin M, Omar K, Kaur P. Psychiatric morbidity among adult patients in a semi-urban primary care setting in Malaysia. International journal of mental health systems. 2009;3(1):13.

24. Srinivasan M, Reddy MM, Sarkar S, Menon V. Depression, Anxiety, and Stress among Rural South Indian Women-Prevalence and Correlates: A Community-Based Study. Journal of Neurosciences in Rural Practice. 2020;11(01):078-83.

25. Jadhav A, Weir D. Widowhood and depression in a cross-national perspective: Evidence from the United States, Europe, Korea, and China. The Journals of Gerontology: Series B. 2018;73(8):e143-e53.

26. Vable AM, Subramanian S, Rist PM, Glymour MM. Does the "widowhood effect" precede spousal bereavement? Results from a nationally representative sample of older adults. The American Journal of Geriatric Psychiatry. 2015;23(3):283-92.

27. Vilsaint CL, NeMoyer A, Fillbrunn M, et al. Racial/ethnic differences in 12-month prevalence and persistence of mood, anxiety, and substance use disorders: Variation by nativity and socioeconomic status. Compr Psychiatr. 2019;89:52-60.

28. Donaldson SI, Dollwet M, Rao MA. Happiness, excellence, and optimal human functioning revisited: Examining the peer-reviewed literature linked to positive psychology. The Journal of Positive Psychology. 2015;10(3):185-95.

29. Hajebi A, Motevalian SA, Rahimi-Movaghar A, et al. Major anxiety disorders in Iran: prevalence, sociodemographic correlates and service utilization. BMC Psychiatry. 2018;18(1):261.

30. Bonful HA, Anum A. Sociodemographic correlates of depressive symptoms: a cross-sectional analytic study among healthy urban Ghanaian women. BMC Public Health. 2019;19(1):50.

31. Zhang S, Bhavsar V. Unemployment as a risk factor for mental illness: combining social and psychiatric literature. Advances in Applied Sociology. 2013;3(02):131.

32. Paul KI, Moser K. Unemployment impairs mental health: Meta-analyses. Journal of Vocational behavior. 2009;74(3):264-82.

33. Andrea H, Bültmann U, van Amelsvoort LG, Kant Y. The incidence of anxiety and depression among employees -the role of psychosocial work characteristics. Depress Anxiety. 2009;26(11):1040-8.

34. Mohammadi M-R, Davidian $H$, Noorbala AA, et al. An epidemiological survey of psychiatric disorders in Iran. Clinical practice epidemiology in mental health. 2005;1(1):16.

35. Eikelenboom M, Beekman AT, Penninx BW, Smit JH. A 6-year longitudinal study of predictors for suicide attempts in major depressive disorder. Psychological medicine. 2019;49(6):911-21. 
36. Ströhle A. Physical activity, exercise, depression and anxiety disorders. J Neural Transm. 2009;116(6):777.

37. Faith $\mathrm{M}$, Butryn $\mathrm{M}$, Wadden $\mathrm{T}$, et al. Evidence for prospective associations among depression and obesity in population-based studies. Obes Rev. 2011;12(5):e438-e53.

38. Amiri S, Behnezhad S. Obesity and anxiety symptoms: A systematic review and meta-analysis. neuropsychiatrie. 2019;33(2):72-89.

39. Puhl RM, Moss-Racusin CA, Schwartz MB, Brownell KD. Weight stigmatization and bias reduction: perspectives of overweight and obese adults. Health Educ Res. 2008;23(2):347-58.

40. Heo M, Pietrobelli A, Wang D, Heymsfield SB, Faith MS. Obesity and functional impairment: influence of comorbidity, joint pain, and mental health. Obesity. 2010;18(10):2030-8.

41. Morrell HE, Cohen LM. Cigarette smoking, anxiety, and depression. Journal of Psychopathology Behavioral Assessment. 2006;28(4):281-95.

42. Sonntag H, Wittchen $H$, Höfler M, Kessler R, Stein M. Are social fears and DSM-IV social anxiety disorder associ7ated with smoking and nicotine dependence in adolescents and young adults? European psychiatry. 2000;15(1):67-74.

43. McCabe RE, Chudzik SM, Antony MM, et al. Smoking behaviors across anxiety disorders. J Anxiety Disord. 2004;18(1):7-18.

44. Shakeri J, Ahmadi SM, Maleki F, et al. Effectiveness of Group Narrative Therapy on Depression, Quality of Life, and Anxiety in People with Amphetamine Addiction: A Randomized Clinical Trial. Iranian Journal of Medical Sciences. 2020;45(2):91.

45. Byrd JB, Brook RD. Anxiety in the "age of hypertension". Curr Hypertens Rep. 2014;16(10):486.

46. Hamer M, Batty GD, Stamatakis E, Kivimaki M. Hypertension awareness and psychological distress. Hypertension. 2010;56(3):547-50.

47. Licht CM, De Geus EJ, Seldenrijk A, et al. Depression is associated with decreased blood pressure, but antidepressant use increases the risk for hypertension. Hypertension. 2009;53(4):631-8.

\section{Figures}




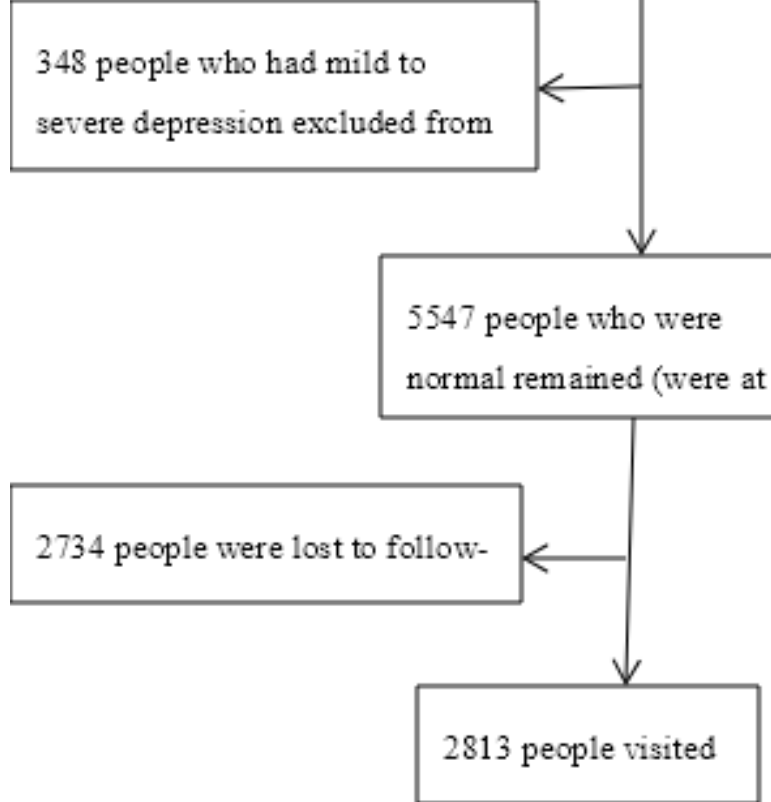

Figure 1

flow chart of people participated in both phases of the study. The data belong to people participated in both phases (2813 persons) were used for incidence rate calculation.
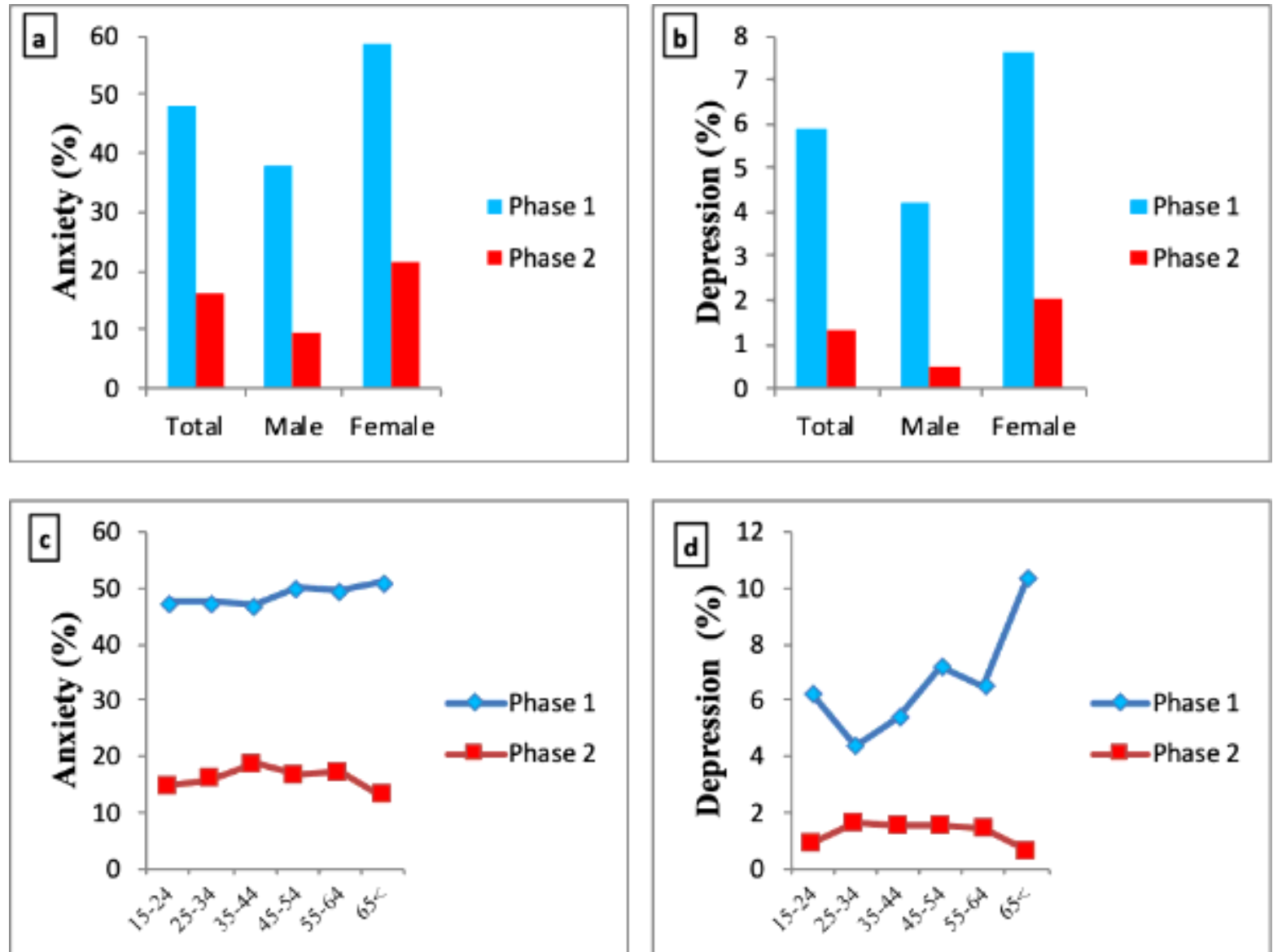

Loading [MathJax]/jax/output/CommonHTML/jax.js 


\section{Figure 2}

The prevalence of anxiety and depression in the participants by sex (a-b) and age (c-d) (total participants = 9996). The data of phase $1(n=5895)$ were used here for comparison and are extracted from the paper published previously [9]. 